\title{
Pengaruh Perubahan Penggunaan Lahan Terhadap Debit Puncak di Sub DAS Penggung Kabupaten Jember
}

\author{
Radhea Giarkenang Nur Fauzi*, Dwiyono Hari Utomo*, Didik Taryana* \\ * Pendidikan Geografi, FIS Universitas Negeri Malang
}

\section{INFO ARTIKEL \\ Riwayat Artikel:}

Diterima: 13-6-2017

Disetujui: 22-9-2017

\section{Kata kunci:}

Perubahan penggunaan

lahan; debit puncak; sub

DAS Penggung

\author{
Alamat Korespondensi: \\ Radhea Giarkenang Nur Fauzi \\ Pendidikan Geografi \\ Universitas Negeri Malang \\ Jalan Semarang No. 5 Malang \\ E-mail: Dhea06nurfauzi@gmail.com
}

\section{PENDAHULUAN}

Sub DAS Penggung merupakan salah satu sub DAS dari DAS Bedadung yang terletak di Kabupaten Jember. Secara astronomis Sub DAS Penggung terletak antara

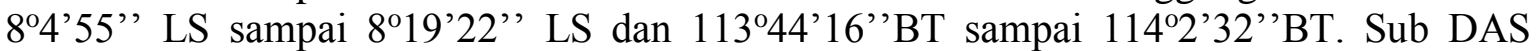
Penggung memiliki luas 573,26 $\mathrm{km}^{2}$.Secara administrasi Sub DAS Penggung terdiri dari Kecamatan Kalisat, Kecamatan Ledok Ombo, Kecamatan Mayang, Kecamatan Mumbulsari, Kecamatan Silo, Kecamatan Sukowono dan Kecamatan Sumber Jambe. 
Peningkatan jumlah penduduk yang semakin bertambah setiap tahunnya di wilayah Sub DAS Penggung juga berdampak pada kebutuhan lahan yang semakin bertambah pula. Perubahan kawasan hutan dan lahan pertanian menjadi lahan pemukiman dan berbagai peruntukan lainnya telah menimbulkan banyak dampak negatif terhadap sumberdaya lahan dan air yang terjadi pada wilayah daerah aliran sungai (DAS). Perubahan penggunaan lahan adalah bertambahnya suatu penggunaan lahan dari satu sisi penggunaan ke penggunaan lainnya yang diikuti dengan berkurangnya type penggunaan lahan yang lain dari suatu waktu ke waktu berikutnya, atau berubahnya fungsi suatu lahan pada kurun waktu yang berbeda (Sunaryo Dkk, 2001). Menurut Chapin Jr. dan Kaiser Edward (1995) bahwa pola penggunaan lahan dalam berbagai bentuk dan cara akan berdampak terhadap lingkungan. Banjir, kekeringan, erosi, sedimentasi, dan abrasi merupakan beberapa indikasi terjadinya penurunan daya dukung lingkungan di suatu wilayah. Hal ini terbukti dengan terjadinya fenomena bencana banjir bandang yang terjadi pada tahun 2006. Fenomena banjir yang terjadi pada tahun 2006 tersebut terjadi di beberapa kecamatan salah satunya yaitu Kecamatan Sumberjambe dengan debit puncak pada saat banjir mencapai $281,47 \mathrm{~m}^{3} / \mathrm{dt}$, Kecamatan Sumberjambe ini masuk dalam wilayah Sub DAS Penggung (Bappekab dalam Ismiyah, 2013).

Menurut Widiatni (2014) Persentase perubahan penggunaan lahan di Sub DAS Penggung periode tahun 2010 sampai tahun 2012, perubahan penggunaan lahan hutan menjadi permukiman di Sub DAS Penggung mencapai 0,3\%. Perubahan penggunaan lahan dari hutan yang dulunya resapan air menjadi kawasan terbangun yang bersifat kedap air menyebabkan berkurangnya area resapan sehingga menimbulkan limpasan permukaan (surface runoff). Air hujan yang jatuh sebagian besar tidak dapat tertahan oleh vegetasivegetasi dan tidak dapat meresap ke dalam tanah sehingga air hujan tersebut sebagian besar akan menjadi aliran permukaan (Asdak, 2002). Hal ini terbukti dari fenomena genangan pada musim hujan di wilayah Sub DAS Penggung saat ini juga sudah mulai tampak umum dan semakin meluas, terutama pada saat terjadi hujan dengan intensitas tinggi dan cukup lama. Aliran permukaan dalam DAS akan mengalir dan berkumpul pada alur-alur sungai sehingga debit aliran yang mengalir pada sistem drainase akan meningkat.

Debit puncak tertinggi di Sub DAS penggung tahun 2010 sebesar $96,74 \mathrm{~m}^{3} /$ detik dan pada tahun tahun 2015 mencapai 151,43 $\mathrm{m}^{3}$ /detik (UPT PSAWS Bondoyudo Kabupaten Lumajang). Debit puncak yang semakin meningkat setiap tahunnya tidak dapat dihindari. peningkatan debit puncak yang terjadi di wilayah Sub DAS Penggung disebabkan karena berkurangnya luas daerah resapan air akibat perubahan penggunaan lahan karena penggunaan lahan merupakan salah satu faktor yang memiliki pengaruh besar terhadap aliran permukaan yang menyebabkan peningkatan debit sungai.

Berdasarkan permasalahan di atas maka perlu dilakukan penelitian mengenai pengaruh perubahan penggunaan lahan terhadap debit puncak banjir, Penelitian ini dapat digunakan sebagai acuan agar dalam melakukan pembangunan tidak mengesampingkan pentingnya daerah resapan air yang berfungsi untuk meminimalisir terjadinya limpasan permukaan yang berdampak terhadap peningkatan debit puncak. Berdasarkan latar belakang tersebut, maka peneliti mengangkat judul "Pengaruh perubahan penggunaan lahan terhadap debit puncak di Sub DAS Penggung Kabupaten Jember”.

\section{METODE}

Penelitian ini merupakan jenis penelitian kuantitatif dengan metode pengambilan data menggunakan metode dokumentasi dan metode observasi. Pada teknik pengambilan data pada penelitian ini, peneliti melakukan pengumpulan data yang berasal dari dokumen pengelola terhadap kajian yang diteliti yaitu UPT PSAWS Bondoyudo Kabupaten 
Lumajang. Sedangkan observasi dilakukan dengan cara terjun secara langsung ke lapangan. Jenis data yang digunakan untuk mencapai tujuan penelitian meliputi data primer dan data sekunder. Data primer yang digunakan adalah data titik koordinat masing-masing penggunaan lahan. Data titik koordinat penggunaan lahan diperoleh dengan menentukan titik penggunaan lahan di lapangan secara purpossive sampling sebanyak 10 titik pada masing masing penggunaan lahan. Sedangkan untuk data sekunder yang digunakan adalah Data debit sungai tahun 2006 sampai tahun 2015, Data Curah hujan stasiun Sumber Jambe dan data citra landsat 7 tahun 2006 sampai tahun 2012 dan citra landsat 8 tahun 2013 sampai tahun 2015. Perubahan penggunaan lahan dianalisis menggunakan data citra landsat 7 tahun 2006 sampai tahun 2012 dan citra landsat 8 tahun 2013 sampai tahun 2015 dengan menggunakan teknik klasifikasi terbimbing (Supervised maximum likehood). Peneitian ini ditekankan pada penggunaan lahan hutan, perkebunan, lahan terbangun, sawah, lahan kosong, dan semak/belukar. Teknik analisis data yang digunakan adalah menggunakan statistika inferensial. Teknik analisis data pada statistika inferensial digunakan metode regresi. Analisa pengaruh antara variabel dependen dan variabel independen dilakukan menggunakan regresi linear berganda.

\section{HASIL DAN PEMBAHASAN}

Citra Landsat 7 tahun 2006 sampai dengan tahun 2012 dan Citra Landsat 8 tahun 2013 sampai tahun 2015 lembar Jember yang diperoleh dari hasil download di situs usgs.earthexplorer dilakukan klasifikasi citra supervised di software ArcGis 10.1 dan peroleh data berupa peta penggunaan lahan Sub DAS Penggung mulai tahun 2006 sampai 2015. Jenis penggunaan lahan yang terdapat di Sub DAS Penggung meliputi hutan, perkebunan, lahan terbangun, sawah, lahan kosong dan semak/belukar. Data perubahan luas penggunaan lahan Sub DAS Penggung tahun 2006 sampai dengan tahun 2015 disajikan pada tabel 1 .

Tabel 1. luas perubahan penggunaan lahan di Sub DAS Penggung tahun 2006 sampai $2015\left(\mathrm{Km}^{2}\right)$

\begin{tabular}{|c|c|c|c|c|c|}
\hline \multirow[b]{3}{*}{ No } & \multirow{3}{*}{$\begin{array}{c}\text { Jenis } \\
\text { penggunaan } \\
\text { lahan }\end{array}$} & \multirow{2}{*}{\multicolumn{2}{|c|}{$2015\left(\mathrm{Nm}^{-}\right)$}} & \multirow[b]{3}{*}{$\begin{array}{l}\text { Perubahan } \\
\text { PL }\left(\mathbf{K m}^{2}\right)\end{array}$} & \multirow[b]{3}{*}{$\begin{array}{c}\text { Perubahan } \\
\text { PL (\%) }\end{array}$} \\
\hline & & & & & \\
\hline & & $\begin{array}{c}\text { Luas } \\
\text { Januari } \\
2006\end{array}$ & $\begin{array}{c}\text { Desember } \\
2015\end{array}$ & & \\
\hline 1 & Hutan & 99.58 & 93.16 & -6.42 & -1.12 \\
\hline 2 & Perkebunan & 72.46 & 75.82 & 3.36 & 0.59 \\
\hline 3 & $\begin{array}{l}\text { Lahan } \\
\text { terbangun }\end{array}$ & 141.37 & 152.04 & 10.67 & 1.86 \\
\hline 4 & Sawah & 171 & 166.17 & -4.83 & -0.84 \\
\hline 5 & Lahan kosong & 53.77 & 48.3 & -5.47 & -0.95 \\
\hline 6 & Semak/belukar & 35.08 & 37.77 & 2.69 & 0.47 \\
\hline & Total & 573.26 & 573.26 & & \\
\hline
\end{tabular}

Sumber: Overlay peta PL bulan Januari tahun 2006 dan peta PL bulan Desember tahun 2015

Berdasarkan Tabel 1. penggunaan lahan yang mengalami perubahan paling signifikan adalah lahan terbangun. Lahan terbangun mengalami peningkatan luas sebesar $10,67 \mathrm{~km}^{2}$ atau $1,86 \%$ dari seluruh total luas DAS.

Penggunaan lahan yang mengalami perubahan terbesar kedua yaitu hutan.Tanda negatif menunjukkan terjadi penurunan luas. Hutan mengalami penurunan sebesar $6,42 \mathrm{~km}^{2}$ atau $01,12 \%$ dari total seluruh luas DAS.Penggunaan lahan yang mengalami perubahan terbesar ketiga yaitu lahan kosong. Lahan kosong mengalami penurunan sebesar $5,47 \mathrm{~km}^{2}$ atau $0,95 \%$ dari total seluruh luas DAS. Penggunaan lahan yang mengalami perubahan terbesar ke-empat yaitu sawah. Sawah mengalami penurunan luas sebesar $4,83 \mathrm{~km}^{2}$ atau 
$0,84 \%$ dari total seluruh luas DAS. Penggunaan lahan yang mengalami perubahan terbesar kelima yaitu perkebunan. Hutan mengalami peningkatan luas sebesar $3,36 \mathrm{~km}^{2}$ atau $0,59 \%$ dari total seluruh luas DAS. Penggunaan lahan yang mengalami perubahan terkecil yaitu semak/belukar. Semak/belukar mengalami peingkatan luas sebesar 2,69 $\mathrm{km}^{2}$ atau $0,47 \%$ dari total seluruh luas DAS.

Perubahan penggunaan lahan yang terjadi dari tahun 2006 sampai tahun 2015 terjadi karena penggunaan lahan mengalami perubahan menjadi perubahan lainnya. Bentuk perubahan penggunaan lahan yang terdapat di Sub DAS Penggung disajikan pada tabel 2.

Tabel 2.bentuk perubahan penggunaan lahan Sub DAS Penggung tahun 2006 sampai tahun 2015

\begin{tabular}{clc}
\hline No & Arah perubahan penggunaan lahan & $\begin{array}{c}\text { Luas } \\
\left(\mathbf{K m}^{\mathbf{2}}\right)\end{array}$ \\
\hline 1. & Hutan menjadi perkebunan & 0.26 \\
2. & Hutan menjadi lahan terbangun & 0.72 \\
3. & Hutan menjadi sawah & 4.14 \\
4. & Hutan menjadi lahan kosong & 1.23 \\
5. & Hutan menjadi semak/belukar & 0.67 \\
6. & Perkebunan menjadi lahan terbangun & 0.19 \\
7. & Perkebunan menjadi sawah & 1.49 \\
8. & Perkebunan menjadi lahan kosong & 0.07 \\
9. & Perkebunan menjadi semak/belukar & 1.84 \\
10. & Lahan terbangun menjadi lahan kosong & 0.7 \\
11. & Sawah menjadi perkebunan & 0.17 \\
12. & Sawah menjadi lahan terbangun & 3.54 \\
13. & Sawah menjadi lahan kosong & 1.06 \\
14. & Sawah menjadi semak/belukar & 0.06 \\
15. & Lahan kosong menjadi hutan & 1.03 \\
16. & Lahan kosong menjadi perkebunan & 0.17 \\
17. & Lahan kosong menjadi semak/belukar & 2.45 \\
18. & Lahan kosong menjadi lahan terbangun & 3.11 \\
19. & Lahan kosong menjadi sawah & 1.31 \\
20. & Semak/belukar menjadi hutan & 0.53 \\
22. & Semak/belukar menjadi perkebunan & 1.16 \\
23. & Semak/belukar menjadi lahan & \\
24. & terbangun & 3.18 \\
25. & Semak/belukar menjadi sawah & 1.8 \\
\hline & Total & 0.28 \\
\hline
\end{tabular}

Sumber: Overlay peta penggunaan lahan Sub DAS Penggung tahun 2006 dan tahun 2015

Berdasarkan Tabel 2. dapat diketahui perubahan penggunaan lahan yang terjadi di Sub DAS Penggung. Perubahan penggunaan lahan terluas yaitu hutan menjadi sawah dengan luas mencapai 4,14 $\mathrm{km}^{2}$. Hutan banyak mengalami Perubahan menjadi lahan kosong seluas $1,23 \mathrm{~km}^{2}$, menjadi lahan terbangun seluas $0,72 \mathrm{~km}^{2}$, menjadi perkebunan seluas $0,26 \mathrm{~km}^{2}$ dan menjadi semak/belukar seluas $0,07 \mathrm{~km}^{2}$.

Lahan perkebunan juga mengalami alih fungsi lahan. Perkebunan terbanyak mengalami alih fungsi menjadi sawah seluas $1,49 \mathrm{~km}^{2}$, menjadi lahan terbangun seluas 0,19 $\mathrm{km}^{2}$, menjadi lahan kosong seluas $0,07 \mathrm{~km}^{2}$ dan menjadi semak/belukar $1,84 \mathrm{~km}^{2}$.

Sawah mengalami penurunan luas terbesar ketiga setelah hutan dan lahan kosong. Selama 10 tahun luas sawah mengalami penurunan luas sebesar $4,83 \mathrm{~km}^{2}$.Sawah paling banyak mengalami alih fungsi menjadi lahan terbangun. Perubahan sawah menjadi lahan 
terbangun yaitu seluas $3,54 \mathrm{~km}^{2}$. Sawah juga mengalami alih fungsi menjadi lahan kosong seluas $1,06 \mathrm{~km}^{2}$, menjadi perkebunan seluas $0,17 \mathrm{~km}^{2}$.dan menjadi semak/belukar seluas $0,06 \mathrm{~km}^{2}$.

Lahan kosong paling banyak mengalami alih fungsi menjadi lahan terbangun seluas $3,1 \mathrm{~km}^{2}$, menjadi semak/belukar seluas $1,35 \mathrm{~km}^{2}$, menjadi hutan seluas $0,53 \mathrm{~km}^{2}$, manjadi sawah seluas $0,31 \mathrm{~km}^{2}$ dan menjadi perkebunan seluas $0,17 \mathrm{~km}^{2}$.

Semak/belukar paling banyak mengalami perubahan menjadi lahan terbangun seluas $3,18 \mathrm{~km}^{2}$, menjadi sawah seluas $1,8 \mathrm{~km}^{2}$. menjadi perkebunan seluas $1,16 \mathrm{~km}^{2}$, menjadi hutan seluas $0,53 \mathrm{~km}^{2}$ dan juga menjadi lahan kosong seluas $0,28 \mathrm{~km}^{2}$.

\section{Debit puncak Sub DAS Penggung}

Data debit sungai yang diperoleh dari diperoleh dari UPT PSAWS Bondoyudo Kabupaten Lumajang mulai tahun 2006 sampai tahun 2015 dilihat debit puncaknya berdasarkan hari hujan. Data debit puncak sungai Sub DAS Penggung tahun 2006 sampai tahun 2015 disajikan pada tabel 3.

Tabel 3. Debit puncak Sub DAS Penggungtahun $2006-2015\left(\mathrm{~m}^{3} /\right.$ detik $)$

\begin{tabular}{cccccccc}
\hline \multirow{2}{*}{ No. } & \multirow{2}{*}{ Tahun } & \multicolumn{7}{c}{ Qp $\left(\mathbf{m}^{\mathbf{3}} / \mathbf{d t}\right)$} \\
\cline { 3 - 7 } & & Januari & Februari & Maret & April & November & Desember \\
\hline 1 & 2006 & 123,44 & 86,89 & 89,92 & 43,55 & 19,00 & 43,55 \\
2 & 2007 & 17,70 & 28,82 & 54,45 & 45,95 & 52,40 & 120,73 \\
3 & 2008 & 72,28 & 28,00 & 28,00 & 39,79 & 47,91 & 78,60 \\
4 & 2009 & 79,18 & 54,45 & 41,18 & 56,00 & 20,58 & 57,04 \\
5 & 2010 & 59,67 & 83,89 & 51,90 & 57,56 & 39,79 & 85,69 \\
6 & 2011 & 80,94 & 62,34 & 83,89 & 31,35 & 39,79 & 25,97 \\
7 & 2012 & 65,60 & 53,42 & 112,09 & 44,50 & 19,49 & 65,05 \\
8 & 2013 & 62,88 & 76,86 & 62,88 & 71,15 & 27,18 & 92,37 \\
9 & 2014 & 88,70 & 86,89 & 25,97 & 16,60 & 53,95 & 89,00 \\
10 & 2015 & 32,20 & 65,78 & 54,28 & 52,57 & 70,59 & 134,38 \\
\hline Sumber $:$ UPT PSAWS Bondoyudo Kabupaten Lumajang & & &
\end{tabular}

Tabel 3. menunjukkan data debit puncak sungai Sub DAS Penggung mulai tahun 2006 sampai tahun 2015. Debit puncak di Sub DAS Penggung berfruktuasi. Debit puncak tertinggi pada tahun 2006 terjadi pada bulan Januari yaitu sebesar 123,44 $\mathrm{m}^{3} / \mathrm{dt}$. Pada tahun 2007 debit puncak Sub DAS Penggung tertinggi terjadi pada bulan Desember sebesar 120,73 $\mathrm{m}^{3} / \mathrm{dt}$. Pada tahun 2008 debit puncak Sub DAS Penggung tertinggi sebesar 78,60 $\mathrm{m}^{3} / \mathrm{dt}$ yang terjadi pada bulan Desember.Pada tahun 2009 debit puncak tertinggi terjadi pada bulan Januari sebesar 79,18 m³/dt. Pada tahun 2010 debit puncak tertinggi terjadi pada bulan Februari sebesar $96,711 \mathrm{~m}^{3} / \mathrm{dt}$.Dan pada tahun 2011 debit puncak tertinggi terjadi pada bulan Desember sebesar 246,945 $\mathrm{m}^{3} / \mathrm{dt}$. Pada tahun 2012 debit puncak tertinggi terjadi pada bulan maret sebesar 112,09 m³/dt. Pada tahun 2013 debit puncak Sub DAS Penggung terjadi pada bulan Desember sebesar92,37 $\mathrm{m}^{3} / \mathrm{dt}$. Pada tahun 2014 debit puncak Sub DAS Penggung terjadi pada Desember sebesar 89,00 $\mathrm{m}^{3} / \mathrm{dt}$. Dan tahun 2015 debit puncak tertinggi Sub DAS Penggung terjadi pada bulan Desember sebesar134,38 $\mathrm{m}^{3} / \mathrm{dt}$. Selama kurun waktu 10 tahun debit puncak tertinggi yaitu pada bulan Desember tahun 2015.

\section{Pengaruh luas penggunaan lahan terhadap debit puncak di Sub DAS Penggung}

Berdasarkan hasil analisa statistik dengan menggunakan statistika inferensial metode regresi di software SPSS diketahui nilai korelasi/ hubungan $(\mathrm{R})$ yaitu sebesar 0,569 dan koefisien determinasi $\left(\mathrm{R}^{2}\right)$ Sebesar 0,324 . Koefisien determinasi $\left(\mathrm{R}^{2}\right)$ dapat menjelaskan besarnya prosentase pengaruh variabel bebas terhadap variabel terikat yang mengandung 
pengertian bahwa pengaruh variabel bebas bersama-sama terhadap variabel terikat adalah sebesar 32,4\%.sedangkan sisanya dipengaruhi oleh variabel yang lain.

Pada tabel coefisients dapat dilihat koefisien masing-masing penggunaan lahan. Sehingga persamaan regresinya ditulis dengan persamaan:

$$
\mathrm{Y}=8,837-18,081 \mathrm{X}_{1}+3,601 \mathrm{X}_{2}+10,147 \mathrm{X}_{3}-2,582 \mathrm{X}_{4}+17,053 \mathrm{X}_{5}+8,023 \mathrm{X}_{6}
$$

Berdasarkan output coefisien masing-masing jenis penggunaan lahan dapat dilihat bahwa koefisien regresi variabel hutan $\left(\mathrm{X}_{1}\right)$ dan sawah $\left(\mathrm{X}_{4}\right)$ bernilai negatif dapat dikatakan bahwa hutan $\left(\mathrm{X}_{1}\right)$ dan sawah $\left(\mathrm{X}_{4}\right)$ berpengaruh negatif terhadap debit puncak $(\mathrm{Y})$, maka setiap luas hutan dan sawah mengalami penurunan luas maka debit puncak mengalami kenaikan.koefisien regresi variabel perkebunan $\left(\mathrm{X}_{2}\right)$, lahan terbangun $\left(\mathrm{X}_{3}\right)$, lahan kosong $\left(\mathrm{X}_{5}\right)$ dan semak/belukar $\left(\mathrm{X}_{6}\right)$ bernilai positif maka dapat dikatakan bahwa setiap luasnya bertambah maka terhadap debit puncak (Y) juga mengalami kenaikan.

\section{Hasil uji simultan}

Hasil dari uji regresi simultan yang digunakan untuk mengetahui bersama-sama apakah secara simultan variabel bebas hutan $\left(X_{1}\right)$, perkebunan $\left(X_{2}\right)$, lahan terbangun $\left(X_{3}\right)$, sawah $\left(\mathrm{X}_{4}\right)$, lahan kosong $\left(\mathrm{X}_{5}\right)$ dan semak/belukar $\left(\mathrm{X}_{6}\right)$ memiliki hubungan yang signifikan dengan variabel dependen debit puncak (Y), Maka dilakukan uji signifikansi dengan hipotesis :

$\mathrm{H}_{0}=$ Tidak terdapat pengaruh yang signifikan antara variable bebas $\left(\mathrm{X}_{1}, \mathrm{X}_{2}, \mathrm{X}_{3}, \mathrm{X}_{4}\right.$, $\mathrm{X}_{5}$ dan $\mathrm{X}_{6}$ ) secara bersama-sama terhadap variabel terikat $(\mathrm{Y})$.

$\mathrm{H}_{\mathrm{i}}=$ Terdapat pengaruh yang signifikan antara variable bebas $\left(\mathrm{X}_{1}, \mathrm{X}_{2}, \mathrm{X}_{3}, \mathrm{X}_{4}, \mathrm{X}_{5}\right.$ dan $\mathrm{X}_{6}$ ) secara bersama-sama terhadap variabel terikat $(\mathrm{Y})$.

Pada level of significant, dengan $\alpha=5 \%$. Dengan jumlah sampel (n) sebanyak 60 dan jumlah variabel bebas/independent $(\mathrm{k})$ adalah 6, dari tabel $\mathrm{F}$ diketahui $\mathrm{F}$ tabel adalah 2,39. Dilihat dari output uji regresi F hitung adalah 2,699 dengan nilai Signifikansi sebesar 0,041 maka $\mathrm{F}$ hitung $\geq \mathrm{F}$ tabel, maka $\mathrm{H}_{0}$ ditolak dan Hi diterima. Dan nilai Sig. $<0,05$ maka $\mathrm{H}_{0}$ ditolak dan $\mathrm{H}_{\mathrm{i}}$ diterima. Jadi dapat ditarik kesimpulan bahwa terdapat pengaruh yang signifikan antara variabel bebas $\left(\mathrm{X}_{1}, \mathrm{X}_{2}, \mathrm{X}_{3}, \mathrm{X}_{4}, \mathrm{X}_{5}\right.$ dan $\left.\mathrm{X}_{6}\right)$ secara bersama-sama terhadap variable terikat $(\mathrm{Y})$.

\section{Hasil uji parsial}

Hasil uji regresi parsial untuk mengetahui hubungan antara masing-masing variabel bebas terhadap variabel terikat secara parsial atau pervariabel digunakan uji t dengan formula hipotesis dalam uji regresi parsial sebagai berikut:

$\mathrm{H}_{0}=$ Tidak terdapat pengaruh yang signifikan antara variable bebas $(\mathrm{Xn})$ terhadap variable terikat (Y).

$\mathrm{H}_{\mathrm{i}}=$ Terdapat pengaruh yang signifikan antara variable bebas (Xn) terhadap variabel terikat $(\mathrm{Y})$.

Nilai t hitung dan nilai signifikansi masing-masing penggunaan yang digunakan dalam pengambilan keputusan menolak atau menerima $\mathrm{H}_{0}$ disajikan pada tabel 4 . 
Tabel 4. Nilai t hitung dan nilai signifikansi

\begin{tabular}{lcl}
\hline \multicolumn{1}{c}{ Penggunaan lahan } & t hitung & Sig. \\
\hline Hutan & 1.945 & .057 \\
Perkebunan & .273 & .786 \\
Lahan terbangun & 2.098 & .016 \\
Sawah & .299 & .766 \\
Lahan kosong & 2.809 & .007 \\
Semak/belukar & .717 & .476 \\
\hline
\end{tabular}

Berdasarkan Tabel 4. Pada level of significant, dengan $\alpha=5 \%$. Diperoleh $\mathrm{t}$ tabel sebesar 2,0057. Dengan dasar pengambilan keputusan jika nilai thitung $<\mathrm{t}$ tabel atau Sig. $>$ 0,05 maka $\mathrm{H}_{0}$ diterima dan $\mathrm{H}_{\mathrm{i}}$ ditolak dan jika nilai $\mathrm{t}$ hitung $>\mathrm{t}$ tabel atau Sig. $<0,05$ maka $\mathrm{H}_{0}$ ditolak dan $\mathrm{H}_{\mathrm{i}}$ diterima. Karena nilai t hitung < t tabel atau Sig. $>0,05$ maka $\mathrm{H}_{0}$ diterima dan $\mathrm{H}_{\mathrm{i}}$ ditolak.

$\mathrm{T}$ hitung hutan sebesar 1,945 dengan nilai signifikansi 0,057.t hitung $<\mathrm{t}$ tabel atau Sig. > 0,05 maka $\mathrm{H}_{0}$ diterima dan $\mathrm{H}_{\mathrm{i}}$ ditolak, Jadi dapat ditarik kesimpulan bahwa tidak terdapat pengaruh yang signifikan antara hutan $\left(\mathrm{X}_{1}\right)$ terhadap debit puncak $(\mathrm{Y})$.

Nilai t hitung perkebunan adalah 0.273 dengan nilai signifikansi sebesar 0.786.maka nilai t hitung $<\mathrm{t}$ tabel atau Sig. $>0,05$ maka $\mathrm{H}_{0}$ diterima dan $\mathrm{H}_{\mathrm{i}}$ ditolak. Jadi dapat ditarik kesimpulan bahwa tidak terdapat pengaruh yang signifikan antara perkebunan $\left(\mathrm{X}_{2}\right)$ terhadap debit puncak (Y).

Nilai t hitung lahan terbangun adalah 2,097 dengan nilai signifikansi sebesar 0,016.maka nilai t hitung $>\mathrm{t}$ tabel atau Sig. $<0,05$ maka $\mathrm{H}_{0}$ ditolak dan $\mathrm{H}_{\mathrm{i}}$ diterima. Jadi dapat ditarik kesimpulan bahwa terdapat pengaruh yang signifikan antara lahan terbangun $\left(\mathrm{X}_{3}\right)$ terhadap debit puncak $(\mathrm{Y})$.

Nilai thitung sawah adalah 0,299 dengan nilai signifikansi sebesar 0.766, maka nilai t hitung < t tabel dan nilai Sig. > 0,05. maka $\mathrm{H}_{0}$ diterima dan $\mathrm{H}_{\mathrm{i}}$ ditolak. Jadi dapat ditarik kesimpulan bahwa tidak terdapat pengaruh yang signifikan antara sawah $\left(\mathrm{X}_{4}\right)$ terhadap debit puncak (Y).

Nilai t hitung lahan kosong adalah 2,809 dengan nilai signifikansi sebesar 0.007.maka nilai $\mathrm{t}$ hitung $>\mathrm{t}$ tabel atau Sig. $<0,05$ maka $\mathrm{H}_{0}$ ditolak dan $\mathrm{H}_{\mathrm{i}}$ diterima. Jadi dapat ditarik kesimpulan bahwa terdapat pengaruh yang signifikan antara lahan kosong $\left(\mathrm{X}_{5}\right)$ terhadap debit puncak (Y).

Nilai t hitung Semak/ belukar adalah 0,717 dengan nilai signifikansi sebesar 0.47.nilai $\mathrm{t}$ hitung < tabel dan nilai Sig. > 0,05. maka $\mathrm{H}_{0}$ diterima dan $\mathrm{H}_{\mathrm{i}}$ ditolak. Jadi dapat ditarik kesimpulan bahwa tidak terdapat pengaruh yang signifikan antara semak/ belukar $\left(\mathrm{X}_{6}\right)$ terhadap debit puncak $(\mathrm{Y})$.

Hasil dari penelitian dengan menggunakan klasifikasi supervised pada Citra Landsat 7 tahun 2006-2012 dan Landsat 8 tahun 2013-2015 menunjukkan jenis penggunaan lahan di Sub DAS Penggung terdiri dari hutan, perkebunan, lahan terbangun, sawah, lahan kosong dan semak/ belukar. Pada Januari tahun 2006 penggunaan lahan didominasi lahan sawah seluas $171 \mathrm{~km}^{2}$ atau $29,83 \%$. Terluas kedua yaitu penggunaan lahan lahan terbangun dengan luas $141,37 \mathrm{~km}^{2}$ atau $0,25 \%$. dan diikuti dengan hutan seluas $99,58 \mathrm{~km}^{2}$ atau $17,37 \%$, perkebunan seluas $72.46 \mathrm{~km}^{2}$ atau $12,64 \%$ dan lahan kosong seluas $53,77 \mathrm{~km}^{2}$ atau $9,38 \%$. Penggunaan lahan tersempit yaitu semak/ belukar dengan luas $35,08 \mathrm{~km}^{2}$ atau $6,12 \%$.

Pada tahun 2015 keadaan penggunaan lahan masih sama, penggunaan lahan sawah tetap mendominasi dengan luas $166,17 \mathrm{~km}^{2}$ atau 28,99\%. Luas sawah pada tahun 2015 semakin kecil di bandingkan dengan luas sawah pada tahun 2006. Selama kurun waktu 10 tahun sawah mengalami penurunan luas sebesar $4,83 \mathrm{~km}^{2}$ atau $0,84 \%$. Sawah banyak 
mengalami perubahan menjadi lahan terbangun.Perubahan luas sawah menjadi lahan terbangun mencapai $3,54 \mathrm{~km}^{2}$. Sawahjuga banyak mengalami perubahan menjadi lahan kosong dengan luas $1,06 \mathrm{~km}^{2}$ dan menjadi perkebunan seluas $0,17 \mathrm{~km}^{2}$. Sawah paling sedikit dialih fungsikan menjadi semak/belukar seluas $0,06 \mathrm{~km}^{2}$. Alih fungsi lahan sawah menjadi lahan terbangun lebih disebabkan adanya peningkatan jumlah penduduk sehingga menuntut perluasan lahan untuk mendukung aktifitas penduduk.

Terluas kedua yaitu penggunaan lahan terbangun dengan luas $152,04 \mathrm{~km}^{2}$ atau 26,52\%. Luas lahan terbangun pada tahun 2015 semakin besar di bandingkan dengan luas lahan terbangun pada tahun 2006. Selama kurun waktu 10 tahun lahan terbangun mengalami peningkatan luas sebesar $10,67 \mathrm{~km}^{2}$ atau $1,86 \%$. Peningkatan luas lahan terbangun dapat diketahui akibat adanya peningkatan jumlah penduduk. Jenis penggunaan lahan hutan dan sawahlah yang menjadi permukiman atau lahan terbangun lainnya. Menurut Wijaya (2011) pada daerah yang memiliki aksesibilitas tinggi seperti hutan dan sawah yang terdapat di pinggir jalan raya dan mempunyai peluang besar untuk berkembang. Perubahan hutan dan sawah menjadi lahan terbangun biasanya berupa pertokoan dan perumahan.Semakin meningkatnya lahan terbangun menyebabkan area resapan menjadi semakin sempit sehingga menimbulkan limpasan permukaan (surface runoff). Air hujanyang jatuh sebagian besar tidak dapat tertahan oleh vegetasi-vegetasi dan tidak dapat meresap ke dalam tanah sehingga air hujan tersebut sebagian besar akan menjadi aliran permukaan (Asdak, 2010).

Terluas ketiga yaitu penggunaan lahan hutan dengan luas $93,16 \mathrm{~km}^{2}$ atau $16,25 \%$. Padahal dalam UU No. 41 tahun 1999 minimal luas hutan dalam suatu DAS adalah 30\% dari keseluruhan luas DAS. Luas lahan hutan pada tahun 2015 semakin kecil di bandingkan dengan luas hutan pada tahun 2006. Padahal fungsi hutan dapat mengurangi erosi yang menyebabkan pendangkalan di sungai. Sehingga fungsi hutan ini lebih menjaga saluran sungai agar lancar mengalirkan air (Dunne dan Leopold (1978) dalam Erstayudha (2008). Pendapat tersebut juga diperkuat oleh Asdak (2010) yang menyebutkan bahwa keberadaan hutan dapat dipandang sebagai kegiatan pendukung dari usaha lain dalam menurunkan terjadinya banjir. Selain itu hutan berfungsi dalam menjaga kontinuitas aliran, karena hutan dapat mengatur tata air yaitu menampung air pada musim penghujan dan mengalirkannya pada musim kemarau.

Selama kurun waktu 10 tahun, hutan mengalami penurunan luas sebesar $6,42 \mathrm{~km}^{2}$ atau $1,12 \%$. Hutan paling banyak berubahmenjadi sawah dengan luas mencapai 4,14 $\mathrm{km}^{2}$.Hutan juga banyak berubah menjadi lahan kosong seluas $1,23 \mathrm{~km}^{2}$. Hutan juga menjadi lahan terbangun seluas $0,72 \mathrm{~km}^{2}$ menjadi perkebunan seluas $0,26 \mathrm{~km}^{2}$ dan paling sedikit berubah menjadi semak/belukar seluas $0,07 \mathrm{~km}^{2}$.

Terluas ke-empat yaitu penggunaan lahan perkebunan dengan luas $75,82 \mathrm{~km}^{2}$ atau 13,23\%. Luas lahan perkebunan pada tahun 2015 semakin besar di bandingkan dengan luas perkebunan pada tahun 2006. Selama kurun waktu 10 tahun perkebunan mengalami peningkatan luas sebesar $3,36 \mathrm{~km}^{2}$ atau $0,59 \%$. Lahan perkebunan yang terdapat di Sub DAS Penggung banyak dialih fungsikan menjadi sawah sawah seluas $1,49 \mathrm{~km}^{2}$. Terluas kelima yaitu lahan kosong dengan luas $48,3 \mathrm{~km}^{2}$ atau $8,43 \%$. Luas lahan kosong pada tahun 2015 lebih sempit di bandingkan dengan luas pada tahun 2006. Selama kurun waktu 10 tahun lahan kosong mengalami penurunan luas sebesar $5,47 \mathrm{~km}^{2}$ atau $0,95 \%$. Lahan kosong banyak dialih fungsikan menjadi lahan terbangun seluas $3,11 \mathrm{~km}^{2}$. Lahan kosong banyak dialih fungsikan menjadi lahan terbangun karena semakin meningkatnya pembangunan perumahan yang terdapat di wilayah Sub DAS Penggung.

Penggunaan lahan tersempit yang terdapat di Sub DAS Penggung adalah semak/belukar dengan luas $34,77 \mathrm{~km}^{2}$ atau $6,07 \%$. Luas semak/ belukar pada tahun 2015 lebih besar di bandingkan dengan luas pada tahun 2006. Selama kurun waktu 10 tahun 
semak/belukar mengalami peningkatan luas sebesar $2,69 \mathrm{~km}^{2}$ atau $0,47 \%$. Peningkatan semak/belukar disebabkan oleh lahan yang dulunya merupakan lahan kosong ditumbuhi dengan semak/ belukar atau rerumputan.

\section{Pengaruh luas penggunaan lahan terhadap debit puncak di Sub DAS Penggung}

Berdasarkan hasil analisa statistik pengaruh luas penggunaan lahan secara bersamasama terhadap debit puncak adalah sebesar 32,4\%.sedangkan sisanya dipengaruhi oleh variabel yang lain.Pengaruh luas penggunaan lahan terhadap debit puncak terdapat pengaruh namun pengaruhnya tidak begitu signifikan. Faktor lain yang dapat berpengaruh terhadap berasal dari jenis dan sifat tanah, Luas dan bentuk DAS, geologi dan kemiringan lereng.

Faktor yang berpengaruh terhadap peningkatan debit puncak yaitu luas DAS. Sub DAS Penggung merupakan Salah satu Sub DAS dari DAS Bedadung. DAS Bedadung merupakan DAS terbesar yang terdapat di Kabupaten Jember. Sub DAS Penggung merupakan Sub DAS yang terluas yaitu dengan luas 573,26 $\mathrm{km}^{2}$. Makin luas DAS makin besar daya tampung, berarti makin besar volume air yang dapat disimpan dan disumbangkan oleh DAS (Asdak, 2010).

Faktor lain yang berkontribusi besar terhadap peningkatan debit puncak yaitu jenis tanah. Jenis tanah yang terdapat di Sub DAS Penggung yaitu tanah inseptisol. Tanah inseptisol merupakan tanah yang paling mendominasi di wilayah Sub DAS Penggung. Tanah ini memiliki daya infiltrasi yang rendah dengan luas tanah sebesar $351,18 \mathrm{~km}^{2}$ atau meliputi sekitar 61,26\%. Arsyad (1989) menyatakan bahwa ada beberapa sifat tanah yang mempengaruhi kepekaan tanah terhadap limpasan permukaan yaitu tekstur tanah, bentuk dan kamantapan strukur tanah, daya ilfiltrasi, permeabilitas tanah, kandungan bahan organik, kapasitas liat, tebal horizon, dan kadar air. Tanah yang banyak mengandung bahan organik akan memperbesar nilai infiltrasi dan menpengruhi limpasan permukaan.Buruknya tanah inseptisol ini karena pada kebanyakan parameternya tidak mempunyai respon yang baik terhadap hidrologi, seperti kandungan air yang rendah, kandungan debu dan liat yang cukup tinggi dan kandungan pasir yang rendah. Tanah yang memiliki kandungan debu dan liat yang tinggi biasanya mempunyai kapasitas infiltrasi lebih rendah. Semakin tinggi kandungan debu dalam tanah maka tanah menjadi semakin resisten tidak menyimpan air melainkan mengalirkanya sehingga menjadi limpasan air dan peka terhadap erosi.

Bentuk topografi DAS seperti kelerengan, derajat kemiringan sistem drainase dan keberadaan cekungan penyimpan air di permukaan juga berpengaruh pada volume dan debit limpasan permukaan.Di Sub DAS Penggung memiliki kemiringan lereng dari sangat curam (> 45\%), curam (25-45\%), agak curam (15-25\%), landai (8-15\%) dan datar(0-8\%). Kondisi kemiringan lereng yang berkontribusi terhadap peningkatan debit puncak yaitu pada lereng yang terdapat pada bagian hulu DAS yang memiliki kemiringan lereng sangat curam (>45\%), curam (25-45\%), agak curam (15-25\%). Hal ini karena pada daerah yang memiliki kemiringan lereng tersebut Aliran permukaan dapat terkonsentrasi menuju sungai dalam waktu singkat.

Geologi juga berpengaruh terhadap limpasan permukaan. Suatu formasi geologi yang mempunyai kemampuan untuk menyimpan dan meloloskan air. Geologi berpengaruh terhadap limpasan yaitu permeabilitas dan kapasitas akuifer batuan ada yang kedap air (sulit ditenbus air) dan ada pula yang lolos air.

Variabel lain yang merupakan salah satu faktor yang mempengaruhi adanya banjir menurut Haryono (2005) adalah adanya kejadian hujan dengan intensitas hujan yang tinggi pada satu waktu. Hujan berpengaruh terhadap limpasan yang meliputi tipe, lama, intensitas dan sebaran hujan sangat menentukan limpasan permukaan yang terjadi di suatu daerah 
aliran sungai (DAS). Jumlah (volume) dan debit limpasan yang terjadi di suatu DAS sangat berkaitan dengan intensitas dan lamanya hujan yang terjadi di DAS yang bersangkutan.

Selain itu, kondisi-kondisi seperti topografi, tanah dan kondisi geologi dalam wilayah Sub DAS Penggung itu tidak sama dan jumlah curah hujan juga tidak sama pula, maka curah hujan yang distribusinya tidak merata yang dapat mengakibatkan debit puncak yang tinggi. Banjir yang terjadi pada suatu DAS yang besar terjadi oleh curah hujan lebat yang distribusinya merata dan sering kali terjadi oleh curah hujan biasa yang mencakup daerah luas meskipun intensitasnya kecil.

Berdasarkan output coefisien masing-masing jenis penggunaan lahan dapat dilihat bahwa koefisien hutan, perkebunan, sawah, lahan kosong dan semak/belukar bernilai negatif maka semakin kecil luas hutan, perkebunan, sawah, lahan kosong dan semak/belukar maka debit puncak akan semakin tinggi. Apabila terdapat tumbuhan maka air hujan yang jatuh akan tertahan oleh tajuk vegetasi. Sebagian air hujan akan tersimpan di permukaan tajuk/ daun selama proses pembasahan tajuk sebagian lainnya akan jatuh keatas permukaan tanah melalui sela sela daun atau mengalir ke bawah permukaan batang pohon. Sebagian lainnya tidak akan sampai ke permukaan tanah melainkan akan terevaporasi kembali ke atmosfer selama dan setelah berlangsungnya hujan. Sebagian lagi mencapai permukan tanah dan terinfiltrasi.

Koefisien regresi lahan terbangun yang bernilai positif dapat dikatakan bahwa lahan terbangun $\left(\mathrm{X}_{3}\right)$ berpengaruh positif terhadap debit puncak $(\mathrm{Y})$. maka setiap luas lahan terbangun mengalami peningkatan luas maka debit puncak mengalami kenaikan. Ini sesuai dengan Asdak (2002), kawasan terbangun yang bersifat kedap air menyebabkan berkurangnya area resapan sehingga menimbulkan limpasan permukaan (Surface runoff). Air hujan yang jatuh sebagian besar tidak dapat tertahan oleh vegetasi-vegetasi dan tidak dapat meresap ke dalam tanah sehingga air hujan tersebut sebagian besar akan menjadi aliran permukaan. Aliran permukaan dalam DAS akan mengalir dan berkumpul pada alur-alur sungai sehingga debit aliran yang mengalir pada sistem drainase akan meningkat.

Berdasarkan hasil uji regresi secara simultan diketahui F hitung adalah 2,699 dengan nilai Signifikansi sebesar 0,027 maka $\mathrm{F}$ hitung $\geq \mathrm{F}$ table, maka $\mathrm{H}_{0}$ ditolak dan Hi diterima. Dan nilai Sig. $<0,05$ maka $\mathrm{H}_{0}$ ditolak dan $\mathrm{H}_{\mathrm{i}}$ diterima. Jadi dapat ditarik kesimpulan bahwa terdapat pengaruh yang signifikan antara variabel bebas $\left(\mathrm{X}_{1}, \mathrm{X}_{2}, \mathrm{X}_{3}, \mathrm{X}_{4}, \mathrm{X}_{5}\right.$ dan $\left.\mathrm{X}_{6}\right)$ secara bersama-sama terhadap variable terikat (Y).dari hasil uji simultan ini membuktikan bahwa penggunaan lahan berpengaruh terhadap debit puncak. Ini sesuai dengan Dewajati (2003) menjelaskan bahwa 3 faktor yang berpengaruh besar terhadap aliran permukaan adalah luas dan bentuk DAS, topografi dan tata guna lahan. Dari pernyataan tersebut penggunaan lahan berpengaruh terhadap respon DAS terutama padaperubahan debit puncak banjir, karena faktor luas, bentuk dan topografi tidak terjadiperubahan pada tahun 2006 hingga tahun 2015.

Berdasarkan uji regresi secara parsial diperoleh nilai t hitung lahan terbangun dan lahan kosong lebih besar dari t tabel dan Sig. < 0,05 maka $\mathrm{H}_{0}$ ditolak dan $\mathrm{H}_{\mathrm{i}}$ diterima. Jadi, lahan terbangun dan lahan kosong yang memiliki pengaruh paling signifikan terhadap debit puncak.

Jenis penggunaan lahan yang paling signifikan pengaruhnya terhadap debit puncak yaitu lahan terbangun. Selama kurun waktu 10 tahun, lahan terbangun mengalami peningkatan luas sebesar $3,36 \mathrm{~km}^{2}$.Peningkatan lahan terbangun menyebabkan berkurangnya area resapan.Lahan terbangun biasanya terbuat dari beton, aspal dan material tutupan lahanyang tidak dapat tembus air. Air hujan yang tidak terserap kedalam tanah akan tertampung sementara dalam cekungan cekungan permukaan tanah untuk kemudian mengalir ketempat yang lebih rendah (run off) untuk selanjutnya mengalir ke dalam sungai. 
Maka semakin banyak limpasan permukaan maka semakin banyak pula air yang masuk ke dalam sungai. Hal inilah yang menyebabkan semakin tinggi debit puncaknya.

Selama kurun waktu 10 tahun lahan kosong mengalami penurunan seluas $5,47 \mathrm{~km}^{2}$ atau $0,95 \%$. Lahan kosong banyak mengalami perubahan menjadi lahan terbangun.Penurunan luas lahan kosong berpengaruh terhadap peningkatan debit puncak karena apabila lahan kosong mengalami perubahan menjadi lahan terbangun maka area resapan semakin berkurang pula. Pada saat musim hujan, air hujan yang jatuh tidak dapat terserap ke dalam tanah tetapi langsung menjadi limpasan permukaan.

\section{KESIMPULAN} berikut:

Berdasarkan hasil penelitian dan pembahasan dapat ditarik kesimpulan sebagai

1. Jenis penggunaan lahan yang terdapat di Sub DAS Penggung yaitu hutan, perkebunan, lahan terbangun, sawah, lahan kosong dan semak/ belukar. Penggunaan lahan paling mendominasi di wilayah Sub DAS Penggung yaitu sawah. Lahan yang paling banyak mengalami perubahan yaitu hutan. Hutan mengalami penurunan luas sebesar $6,42 \mathrm{~km}^{2}$ atau $1,12 \%$. Hutan banyak mengalami alih fungsi menjadi sawah dengan luas mencapai $4,14 \mathrm{~km}^{2}$.

2. Pengaruh luas penggunaan lahan terhadap debit puncak adalahsebesar $32,4 \%$. Terdapat pengaruh yang signifikan luas penggunaan lahan terhadap debit puncak. Luas penggunaan lahan yang berpengaruh signifikan terhadap debit puncak yaitu lahan terbangun dan lahan kosong. Penggunaan lahan yang paling berpengaruhterhadap debit puncak yaitu lahan terbangun.

\section{DAFTAR RUJUKAN}

Asdak, Chay. 2010. Hidrologi dan Pengelolaan Daerah Aliran Sungai. Yogyakarta: Gadjah Mada University Press.

Arsyad, S. 2010. Konserversi Tanah dan Air. Bogor: IPB Press.

Budiyanto, 2002. Sistem Informasi Geografi menggunakan ArcView GIS. Yogyakarta: Andi.

Cahyono, H. K. 2008. Pengelolaan Daerah Aliran Sungai (DAS) Terpadu(Volume 3) Bandung: Prisma.

Calder, I.R. 1998. Water Resources and Land Use Issu. Syterm Wide Initiative on Water Management. Colombo: Paper No 3. IWMI.

Harisuseno, Donny. 2013.Studi Sebaran Kawasan Resapan (Permeable Area) Pada Berbagai Tipe Penggunaan Lahan. Jurnal Teknik Pengairan, 56 (III):11-28.

I Wayan, Nuarsa. 2005. Manganalisa Data Spasial dengan ArcView GIS 3.3. Bandung:Penerbit Informatika.

Kusumadewi, Ayu. 2012. Arahan Spasial Teknologi Drainase.Bogor: Madani karya.

Lilesand, M.T, Kiefer RW. 1993. Pengindraan Jauh dan Interpretasi Citra. Yogyakarta: Gajah Mada University Press.

Mardi,Wibowo. 2010. Pengaruh perubahan terhadap debit sungai (Studi kasus Sub DAS Cikapundung Gandok. Bandung. Jurnal Teknik Lingkungan.(online), 24 (I): 16-31, (https://publikasiilmiah.ums.ac.id/) di akses 20 Januari 2016.

Sangsongko, Djoko. 1985. Teknik Sumber Daya Air. Jakarta: Erlangga.

Sari, Santi. 2010. Studi limpasan permukaan spasial Akibat perubahan penggunaan lahan (menggunakan model kineros). Malang: Universitas Brawijaya.

Soewarno, 1995. Hidrologi Pengukuran dan Pengelolaan Data Aliran Sungai (Hidrometrik). Bandung: Nova. 
Sosodarsono, S. dan Takeda, K, 1987. Hidrologi Untuk Pengairan. Jakarta: PT.Pradayana Paramita.

Sudaryono. 2002. Pengelolaan Daerah Aliran Sungai (DAS) Terpadu.Bogor: Angkasa.

Triadmodjo, Bambang, 2010. Hidrologi Terapan. Yogyakarta: Beta Offset.

Utaya, Sugeng. 2013. Pengantar Hidrologi. Aditya Malang: Media Publishing.

Utomo, Dwiyono. 2016. Meteorologi Klimatologi. Yogyakarta: Magnum pustaka utama.

Wahyuningtyas, Ayu. 2011.Strategi Penerapan Sumur Resapan Sebagai Teknologi Ekodrainase di Kota Malang (studi kasus: sub das metro).Jurnal Tata Kota dan Daerah. (online), 24 (I): 16-31, (http://www.Worldagroforest.journal.pdf) di akses 20 Januari 2016.

Wiyono, M. 2009. Strategi Penerapan Sumur Resapan Sebagai Teknologi Ekodrainase di Kota Malang. Jurnal Tata Kota dan Daerah, 16 (I):51-58. 